\title{
Alteration of nephrocystins and IFT-A proteins causes similar ciliary phenotypes leading to Nephronophthisis
}

\author{
S Saunier ${ }^{1 *}$, AA Bizet ${ }^{1}$, F Silbermann ${ }^{1}$, E Filhol ${ }^{1}$, T Blisnick ${ }^{2}$, A Henneveu ${ }^{3}$, E Montenont ${ }^{1}$, I Perrault ${ }^{4}$, C Boyle-Feysot $^{5}$ \\ , J-M Rozet ${ }^{4}$, P Bastin², HH Arts ${ }^{6}$, C Antignac ${ }^{1}$, AR Benmerah ${ }^{3}$
}

From First International Cilia in Development and Disease Scientific Conference (2012)

London, UK. 16-18 May 2012

Nephronophtisis (NPH) is a kidney ciliopathy often associated with extra-renal defects and for which 12 genes (NPHP1-12) have been identified. NPHP1 and NPHP4 control the ciliary access at the transition zone and the velocity of some intraflagellar transport (IFT)/BBS proteins in C.elegans. Recently, in a collaborative effort, we have identified, in families with isolated NPH, mutations in $T T C 21 B$ as well as in WDR19, which encode the retrograde IFT-A proteins IFT139 and IFT144, respectively. By ciliome sequencing of 1600 candidate genes from $14 \mathrm{NPH}$ patients followed by Sanger sequencing of a cohort of 52 patients, we have found respectively 8 and 7 patients carrying pathogenic missense mutations in genes coding IFTA proteins, including WDR35, TTC21B and IFT140, which could partially affect their function. Together, these results indicate that IFT-A are involved in nephronophtisis. Moreover, alteration of cilia length was observed in patient kidney, Nphp4-/- mice kidney tubules and NPHP1 or NPHP4 knockdown IMCD3 cell lines. In these cells, primary cilia present swellings at the distal region accompanied by an accumulation of IFT-B at the base and the tip, similar to what was observed in IFT-A mutants, suggesting a possible alteration of retrograde transport. Additionally, ARL13B, a small GTPase required for proper cilium shape and IFT stability, is absent along the axoneme of NPHP4-KD-IMCD cells. By controlling the entry of ciliary components at the transition zone, NPHP1 and NPHP4 may modulate IFT-A cargos thus participating in the same pathway (i.e. Wnt/PCP), alteration of which would lead to renal lesions observed in nephronophthisis.

\footnotetext{
* Correspondence: sophie.saunier@inserm.fr

${ }^{1}$ Inserm U983, France

Full list of author information is available at the end of the article
}

\section{Author details}

${ }^{1}$ Inserm U983, France. ${ }^{2}$ Pasteur Institute, CNRS UMR2581, France. ${ }^{3}$ Inserm U1016, Cochin Institute, France. ${ }^{4}$ Inserm U781, France.

${ }^{5}$ Fondation Imagine, Paris, France. ${ }^{6}$ Radboud University Nijmegen Medical Center, the Netherlands.

Published: 16 November 2012

\section{doi:10.1186/2046-2530-1-S1-P99}

Cite this article as: Saunier et al:: Alteration of nephrocystins and IFT-A proteins causes similar ciliary phenotypes leading to Nephronophthisis. Cilia 2012 1(Suppl 1):P99.
Submit your next manuscript to BioMed Central and take full advantage of:

- Convenient online submission

- Thorough peer review

- No space constraints or color figure charges

- Immediate publication on acceptance

- Inclusion in PubMed, CAS, Scopus and Google Scholar

- Research which is freely available for redistribution

\section{() Biomed Central}

C Biomed Central

C 2012 Saunier et al; licensee BioMed Central Ltd. This is an Open Access article distributed under the terms of the Creative Commons Attribution License (http://creativecommons.org/licenses/by/2.0), which permits unrestricted use, distribution, and reproduction in any medium, provided the original work is properly cited. 